\title{
FÍSICA APLICADA A L'ENSENYAMENT DE L'ARQUITECTURA
}

\author{
Jaume Roset Calzada \\ jaime.roset@upc.edu \\ Arquitectura i energia, Universitat Politècnica de Catalunya \\ Avda Diagonal, 649 ETSAB \\ 08028 Barcelona, Espanya \\ Remissió article: 15-9-2006 Remissió definitiu: 25-9-2006
}

Director de la tesi doctoral: Dr. Rafael Serra Florensa

Paraules clau: Ensenyament, Física per a arquitectes

Resum: L'objectiu de la tesi doctoral (Roset,2006) era descobrir els millors sistemes, procediments i continguts del que hauria d'ésser l'ensenyament de la física en la carrera de arquitectura.

Hem fet la hipòtesi de que millorant la relació entre els llenguatges "matemàtic" i "gràfic", com propis actualment de la física i de l'arquitectura, podrem millorar les dues disciplines.

Hem desenvolupat la hipòtesi treballant sobre COM explicarem els conceptes de física als futurs arquitectes i fixant QUINS conceptes explicarem. A continuació, hem inventat un llenguatge gràfic per a representar els conceptes tant físics com arquitectònics així com les relacions entre ells. Després, hem proposat una manera concreta de fer aquestes explicacions tant per una assignatura com per un capítol concret de la mateixa. L'exemple totalment desenvolupat amb el capítol de Confort Tèrmic de l'assignatura Física de Medi Ambient a l'Arquitectura amb els tests realitzats a 29 estudiants durant la seva impartició ha permès confirmar la hipòtesi del treball i extreure unes altres conclusions inicialment no previstes.

\section{Presentació.}

La gènesi d'aquest treball està en els anys que fa que em dedico a la tasca d'impartir coneixements de física aplicada a l'arquitectura i en una voluntat, crec que lògica, d'arribar millor als estudiants que volen seguir aquest camí. Moltes són les reflexions que he anat fent i, finalment, una d'elles s'ha anat obrint camí: la idea que una explicació feta en un llenguatge que s'acostés al que els estudiants perceben millor podria ajudar a explicar més bé. Un exemple senzill ho explica: La fórmula 1 i la figura 1 mostren el mateix: 
(1)

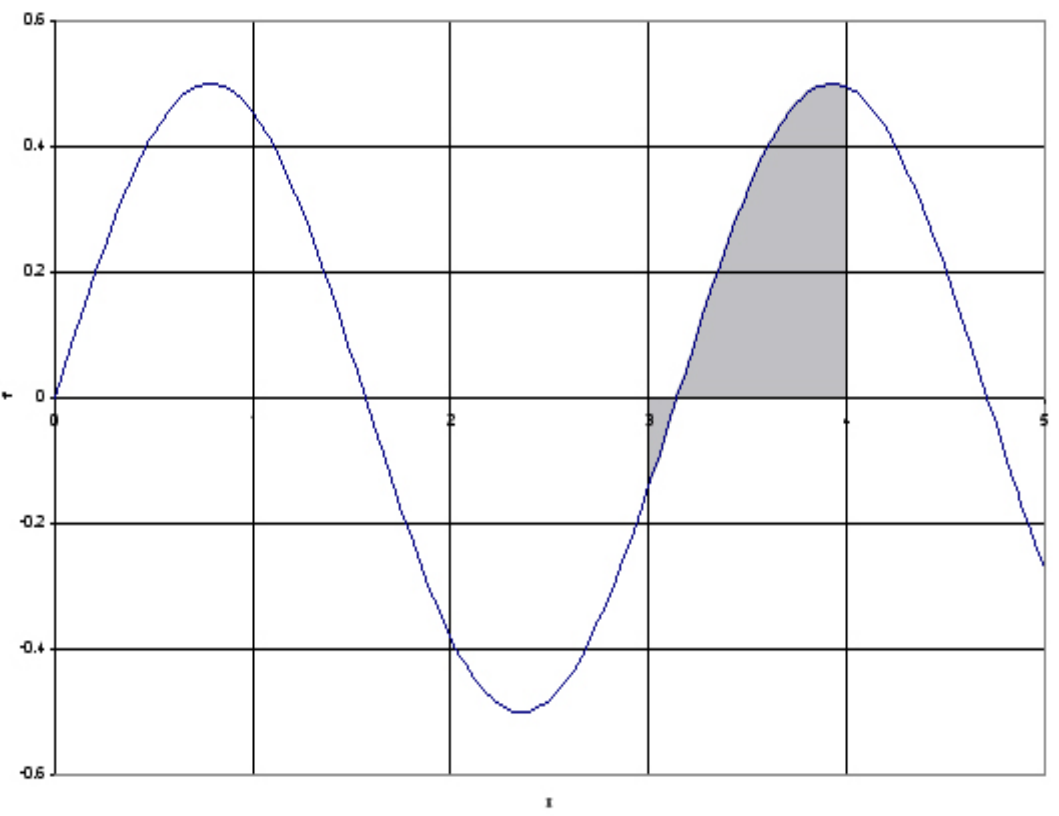

Figura 1. L'espai ratllat indica el mateix valor que la fórmula (1)

En aquest cas, és molt clar l'avantatge que es treu de la presentació gràfica. Això no és tot, però, el llenguatge gràfic és un autèntic canvi de mentalitat. Com a físic, es tracta d'acceptar que les eines gràfiques han arribat a un nivell de sofisticació que, en molts cassos, estan a l'alçada dels mètodes tradicionals d'anàlisi.

Els gràfics son força complets i poden arribar al nivell de realitzar operacions que permeten 'calcular' en el sentit més acurat del terme. En la figura 2, presentem la taula amb els diversos tipus de gràfics que hem identificat. En la darrera línia, els punts (...) signifiquen que poden aparèixer nous tipus de gràfics que arribin a ésser útils en la transmissió de coneixements de física per arquitectes. 


\begin{tabular}{|l|l|l|}
\hline Tipus de gràfic & Breu descripció & L'espai que ens envolta i el \\
pas del temps & & \\
\hline Representació de l'espai & $\begin{array}{l}\text { Codis comuns a un grup de } \\
\text { gent }\end{array}$ & $\begin{array}{l}\text { Dades de variables d'un } \\
\text { fenomen }\end{array}$ \\
\hline Simbòlics & $\begin{array}{l}\text { Construcció } \\
\text { d'operacions }\end{array}$ \\
\hline Visualització de dades & gràfica \\
\hline$\ldots$ & Operatius & \\
\hline
\end{tabular}

Figura 2. Classificació dels gràfics per tipus

Tornem una mica enrere i mirem-nos, nosaltres els físics, més profundament. Si analitzem el treball que realitzem quan "fem física" hom pot veure que és una tasca veritable complexa (figura 3). 


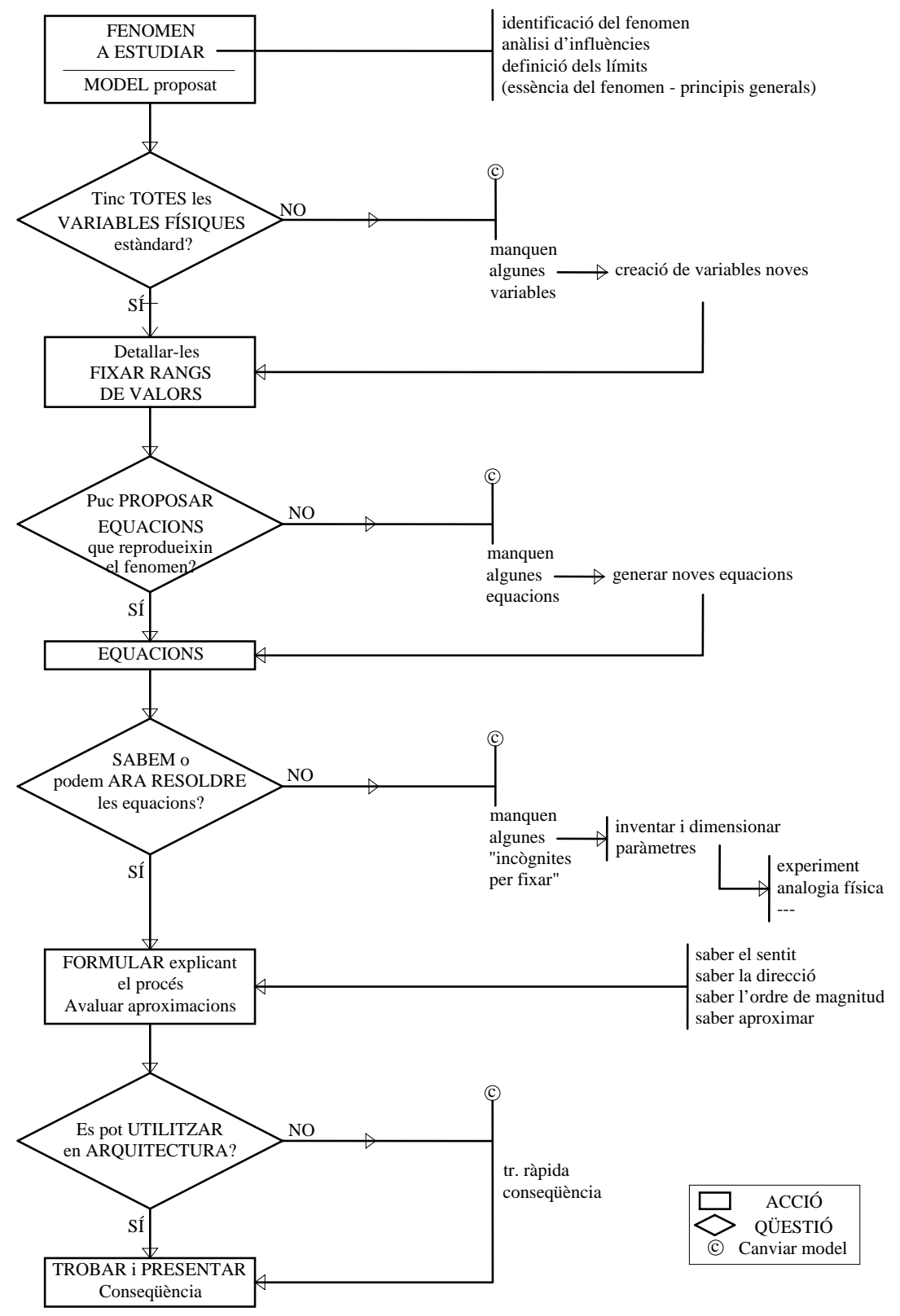

Figura 3. La Física que fem: Els físics realitzem un treball dur i complex cada cop que desenvolupem un tema. Aquest treball, en molts casos, inclou la disposició a fer canvis radicals en el nostre model quan 'no podem' respondre afirmativament a alguna de les qüestions.

Tota aquesta enorme quantitat de feina resta, però, oculta quan es fan la majoria de les explicacions. Així, quan expliquem, únicament transmetem als nostres estudiants la part lineal (figura 4). 


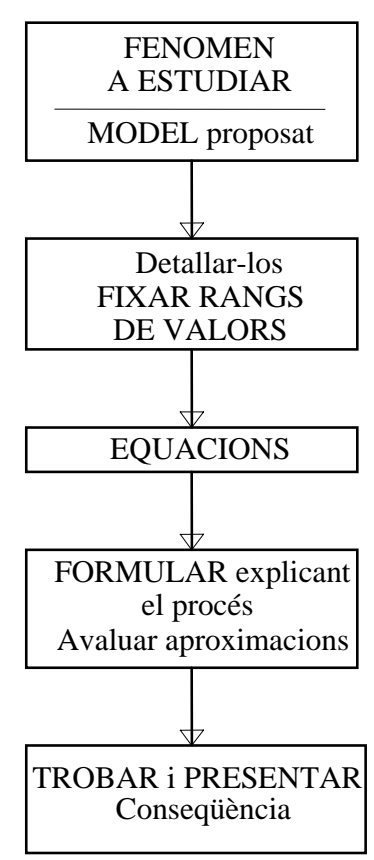

Figura 4. La Física que expliquem: Els físics acostumem a explicar la part lineal de la figura 3.

Vist d'aquesta manera, és evident que els nostres estudiants difícilment ens podran entendre. Fixeu-vos en els gràfics: La figura 4 no permet ni imaginar-se tot el procés real que està descrit en la figura $3 ! !$

El pla que vem fer per a atacar el tema era el següent:

- Un capítol dedicat al COM, on es proposen les condicions que han d'acomplir els "bons" sistemes de transmissió.

- Un capítol dedicat al QUĖ, on es proposen els coneixements de física que cal transmetre als arquitectes incidint especialment en la manera en què s'ha de fer la transmissió.

- Una representació gràfica per a poder treballar còmodament, es va inventar una representació dels conceptes físics a base de rectangles i dels conceptes arquitectònics com a el-lipses i es va desenvolupar.

- Una proposta concreta de sistema de transmissió, s'insisteix en el control dels resultats fent un ús triple dels mateixos. S'assenyala com s'aplicaria a una assignatura i a un capítol.

- Un exemple totalment desenvolupat i provat amb estudiants. S'aplica ho anteriorment explicat a una assignatura particular: Física de Medi Ambient a l'Arquitectura i a un capítol particular: Confort tèrmic. Es mostra la prova que es va realitzar amb 29 estudiants de l'assignatura. 


\section{Sistema de transmissió dels coneixements}

Per què volem aprendre? Què ens fa ensenyar? Creiem que aquest és un dels misteris més profunds de l'ànima humana. Però, per nosaltres, es tracta d'una passió que ens porta a cercar la millor manera de fer-ho. Ens considerarem un emissor que a través d'un medi arriba a un recpetor (que és l'alumne). Com la física és una disciplina científica, els tipus de coneixements en què anem a concentrar-nos seran els que responen al mètode científic.

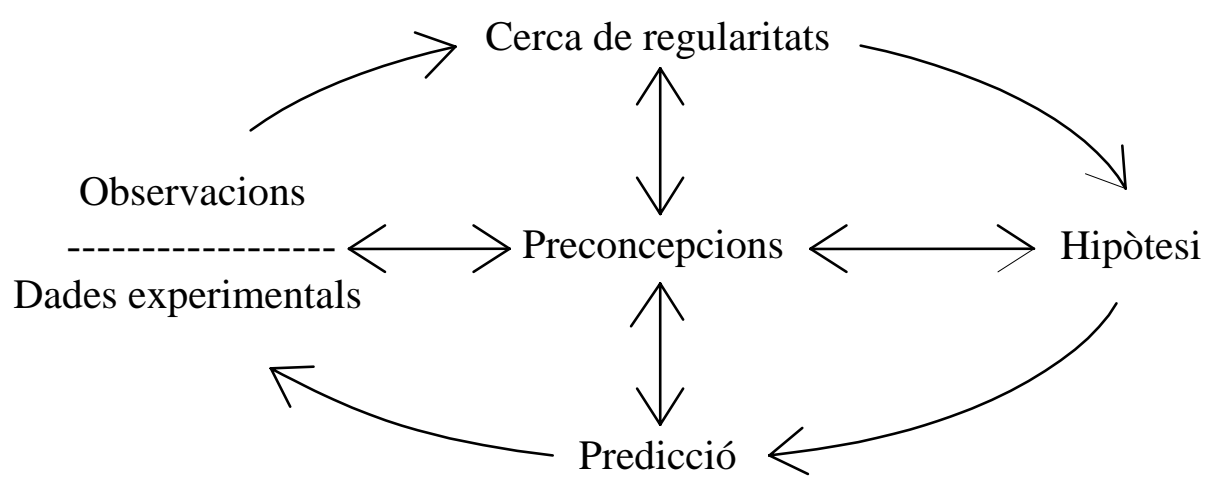

Figura 5. Mètode científic. Observeu la ciclicitat del treball així com la constant relació en dos sentits amb el que ja sabem (les preconcepcions).

En els anys que fa que jo dono classe les coses han canviat molt:

Fa 20 anys

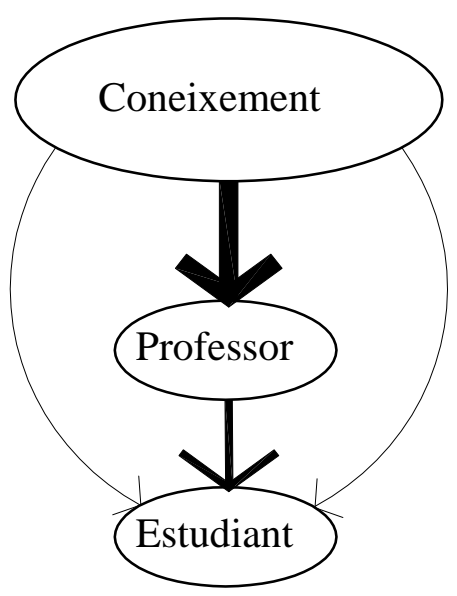

Avui dia

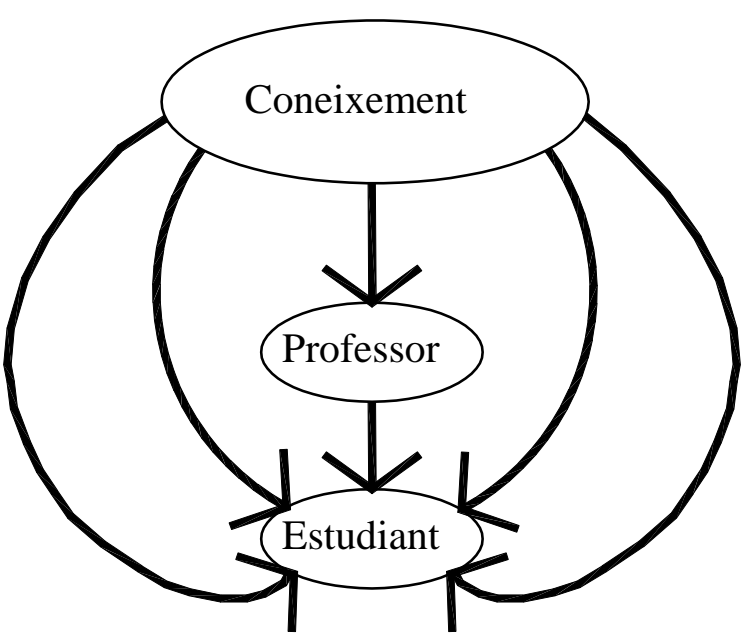

Figura 6. Relació professor estudiant en diferents èpoques 
En un enfocament clàssic de coneixements, habilitats i actituds, pretendrem del nostres estudiants que sàpiguen el que apareix en els programes d'estudis, que siguin capaços de resoldre uns deteminats exercicis i superar uns certs exàmens i estiguin sempre en disposició d'aprendre més i més.

La nostra experiència ens ha portat a concentrar-nos no tant en què voldrem transmetre (tot $i$ que tocarem el tema en l'apartat 3) com en la manera de fer aquesta transmissió. Així, anem a formular unes condicions a acomplir i unes altres a evitar

\begin{tabular}{|c|c|}
\hline+ & - \\
\hline$\frac{\text { Completesa }}{\frac{\text { Claredat }}{\text { Valors }}}$ & $\frac{\text { Saturació }}{\text { Mentides físiques }}$ \\
\hline
\end{tabular}

Taula 1. Condicions a acomplir i a evitar pels bons sistemes de transmissió

Breument, les condicions es poden descriure:

Completesa: Informar a l'alumne de tot el que es pretén explicar. Ho farem des del començament i al llarg de tot el procés. Ens obligarem així a que cada classe i cada conjunt de classes "tinguin un sentit per a l'alumne".

Claredat: Esforçar-nos en preparar models en què "totes i cadascuna de les parts" estiguin ben explicades. La cerca de la claredat no implica de cap manera que haguem de renunciar a utilitzar models abstractes i altament codificats.

Valors: En "totes" les fases del procés hi ha una manera d'obtenir una avaluació. La forma establerta per a l'avaluació ha de poder ésser utilitzada pels estudiants amb la màxima seguretat i rapidesa.

(Evitar) Saturació: Evitar que l'alumne es quedi "ple d'informació". És aquesta una característica invalidant ja que a partir del moment en què s'arriba a la saturació, l'alumne no és capaç d'entendre res més.

(Evitar) Mentides físiques: Evitar passos inexplicables o que donin implicacions falses. És a dir, evitar expressions del tipus "es veu clarament" o "es pot demostrar fàcilment" quan sabem que no és així.

Considerarem que qualsevol transmissió de coneixement organitzat es fa partint d'uns principis bàsics i cercant uns resultats.

Podríem dir que hi ha dues maneres d'establir la correspondència que ens porta als resultats: una forma sòlida i una "discontínua" que reflecteix d'alguna manera si els resultats els hem 
obtingut després de lligar el principi físic a través del procés amb una conseqüència 0 , per altra banda, ho hem fet d'una manera menys clara.

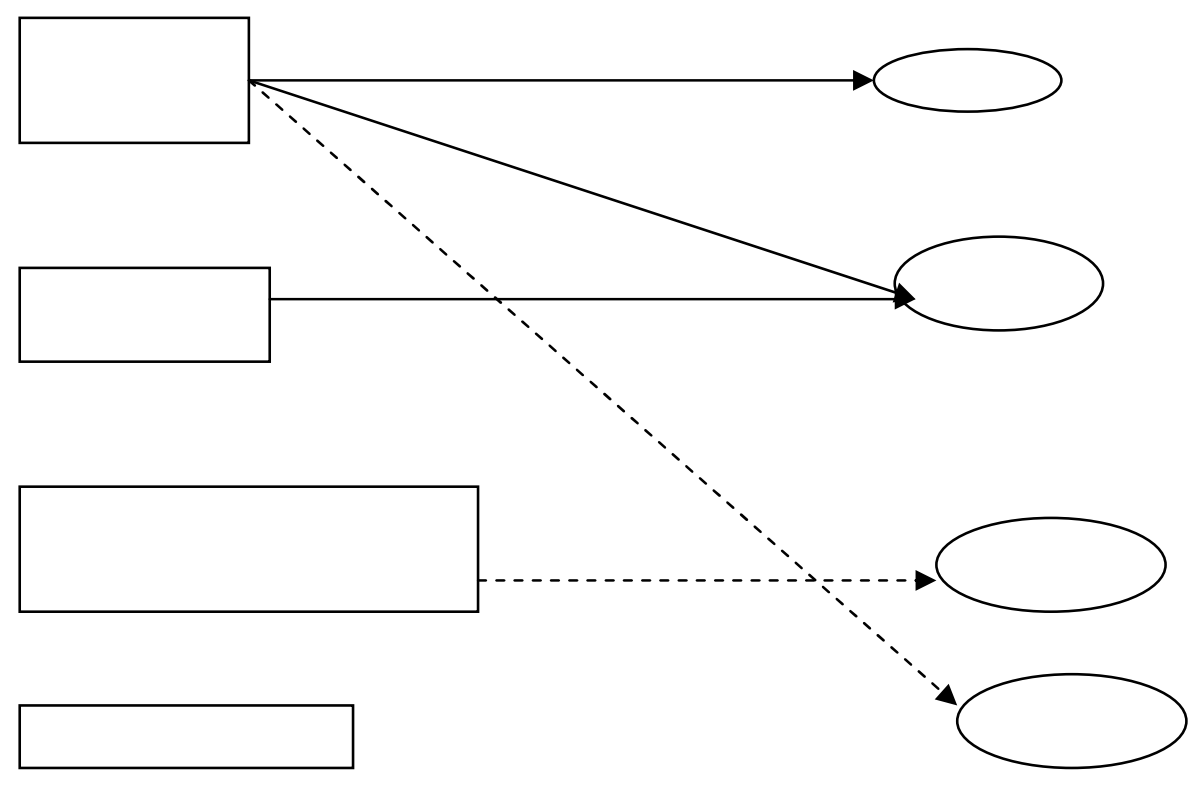

Figura 7. En alguns casos, és possible obtenir uns resultats seguint uns processos ben establerts. En altres (línies discontínues) no és així.

En un treball habitual, podem obtenir diferents tipus de resultats

\begin{tabular}{|l|l|}
\hline I. & Els grans resultats \\
\hline II. & Valors de referència \\
\hline III. & Les “indicacions d'ús més-que-particular" \\
\hline IV. & Resultats utilitaris \\
\hline V. & Resultats laterals... \\
\hline VI. & Sembla que no es pot... \\
\hline
\end{tabular}

Taula 2. Possibles tipus de resultats, Els tipus de resultats en negreta son els resultats "discontinus" als que fèiem referència en la figura anterior.

Cal afegir l'actitud científica que, creiem, ha d'abraçar tota l'activitat que fem i les conclusions que, pensem, cal que donem als estudiants.

En definitiva, nosaltres explicarem partint d'uns principis bàsics, passarem per uns processos que podran ésser ben establerts i portar-nos a unes conseqüències (resultats tipus III, IV i V) 0 menys ben establerts i portar directament a uns resultats d'un tipus diferent (tipus I, II i VI). A continuació, veiem com tots els factors poden ésser posats en correspondència. 


\begin{tabular}{|c|c|c|c|c|c|}
\hline & Completesa & Claredat & $\begin{array}{l}\text { Disposar de } \\
\text { valors }\end{array}$ & $\begin{array}{l}\text { NO } \\
\text { saturació }\end{array}$ & $\begin{array}{l}\text { NO } \\
\text { Mentides } \\
\text { físiques }\end{array}$ \\
\hline Principis & $\begin{array}{l}\text { Segons } \\
\text { categoria } \\
\text { Relació } \\
\text { entre ells }\end{array}$ & $\begin{array}{l}\text { Els menys } \\
\text { 'possible' }\end{array}$ & $\begin{array}{l}\text { Referències } \\
\text { Límits } \\
\text { Pesos, T }\end{array}$ & $\begin{array}{l}\text { Potència } \\
\text { conceptual } \\
\text { elevada }\end{array}$ & $\begin{array}{l}\text { No advertir } \\
\text { limitacions }\end{array}$ \\
\hline Processos & $\begin{array}{l}\text { Justificació } \\
\text { Marc teòric. } \\
\text { Què } \\
\text { calculem i } \\
\text { què no }\end{array}$ & $\begin{array}{l}\text { Llenguatge } \\
\text { familiar } \\
\text { alumne }\end{array}$ & $\begin{array}{l}\text { Referència } \\
\text { cada pas }\end{array}$ & $\begin{array}{l}\text { Massa } \\
\text { informació } \\
\text { Massa } \\
\text { passes }\end{array}$ & $\begin{array}{l}\text { No advertir } \\
\text { limitacions }\end{array}$ \\
\hline $\begin{array}{l}\text { Resultats / } \\
\text { Conseqüències } \\
\text {-Ús més que } \\
\text { particular } \\
\text {-Laterals } \\
\text {-Utilitaris } \\
\end{array}$ & $\begin{array}{l}\text { Qualificar el } \\
\text { procés }\end{array}$ & $\begin{array}{l}\text { Taules } \\
\text { gràfiques }\end{array}$ & $\begin{array}{l}\text { Unitats / } \\
\text { escales } \\
\text { dibuix }\end{array}$ & $\begin{array}{l}\text { Massa } \\
\text { informació. } \\
\text { Poca } \\
\text { precissió }\end{array}$ & $\begin{array}{l}\text { No donar a } \\
\text { entendre el } \\
\text { que sabem } \\
\text { que NO és }\end{array}$ \\
\hline $\begin{array}{l}\text { Resultats / No } \\
\text { Conseqüències } \\
\text {-Gran idea } \\
\text {-Referències } \\
\text {-Sembla que no es } \\
\text { pot }\end{array}$ & $\begin{array}{l}\text { Què es } \\
\text { pretén. } \\
\text { Inventar } \\
\text { variables }\end{array}$ & $\begin{array}{l}\text { Mateix text } \\
\text { ara i al final }\end{array}$ & $\begin{array}{l}\text { Estimació / } \\
\text { tendència }\end{array}$ & $\begin{array}{l}\text { PENSAR } \\
\text { MOLT abans } \\
\text { d'afegir una } \\
\text { variable }\end{array}$ & $\begin{array}{l}\text { No advertir } \\
\text { limitacions. } \\
\text { No confiar }\end{array}$ \\
\hline
\end{tabular}

Taula 3. Implicacions que acomplir o evitar les condicions té sobre la presentació dels principis, processos i resultats.

\section{Situació actual i continguts}

La situació actual és que hi ha moltíssima gent que vol estudiar arquitectura i això ens obliga a organitzar millor la nostra transmissió dels coneixements.

En el treball "Enseñanza y pràctica profesional de la arquitectura en Europa y USA" (Monedero, 2003) es documenten les quantitas d'estudiants "típiques" en les diferents escoles europees, que van des d'escoles d'uns 300/500 estudiants a països com el Regne Unit i Suècia a escoles al voltant dels 15.000 estudiants a Itàlia. Les escoles de l'estat espanyol estarien en una posició intermèdia amb València, Sevilla, Barcelona i Madrid entre 3.000 i 5.000 estudiants.

En els estudis que actualment s'estan fent, el mateix treball ens mostra una proporció d'entre un $15 \%$ i un $30 \%$ de tecnologia. A la Física se li reserva al voltant d'un $2 \%$. Tot i que és molt poc, es pot aprofitar!!

Actualment, amb l'horitzó 2010, estem implicats en el procés de Bologna que intenta aconseguir que tots els títols europeus siguin homologables. A continuació, presentem la figura 8, on podem relacionar els diferents "Resultats" d'Arquitectura que volem assolir a partir de diferents "Principis" de la Física. 

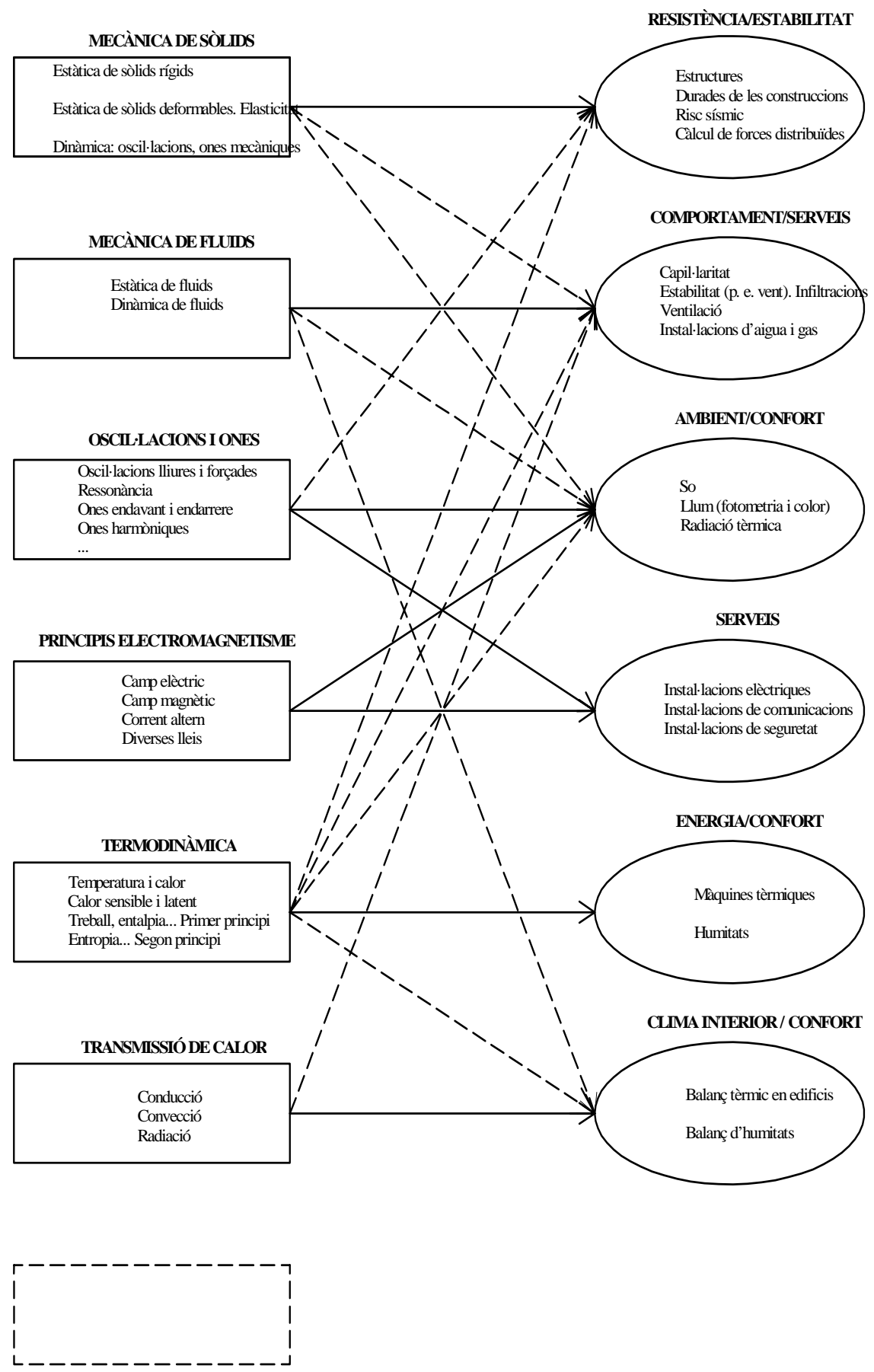

Figura 8. Una proposta de connexió entre temes de Física i d'Arquitectura. 
Es tracta, en resum, dels coneixements de sempre donant l'opció a afegir-ne de nous (el rectangle amb ratlles discontinues) continuen essent adients. El que creiem que serà important és el canvi en el model d'impartició:

- Explicar en classe magistral adaptada a les capacitats dels estudiants d'Arquitectura - amb molt més contingut gràfic, els contingut habituals dels programes.

- Estendre el treball a exercicis més elaborats en col-laboració amb professors d'altres matèries

\section{Representació gràfica de conceptes físico-arquitectònics}

L'arquitecte acostuma a plantejar els conceptes que li interessen d'una manera determinada, son les idees d'allò en que val la pena que els estudiants siguin instruïts. Pot ésser en grans conceptes (Com s'aguanta un edifici?) o en conceptes més petits (Hi ha prou llum per dibuixar amb precisió?). Des d'un punt de vista gràfic representarem aquests conceptes en forma d'el-lipses.
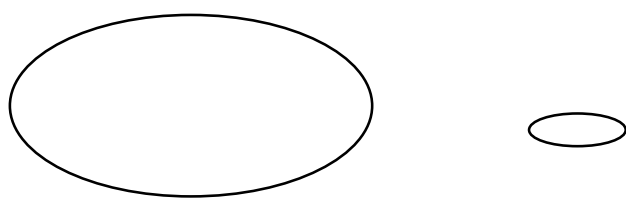

Figura 9. Les el-lipses representaran els conceptes d'arquitectura.

El físic fa les coses d'una altra manera, té una altra forma de valorar el que l'alumne necessitarà. Tot i que també hi ha uns grans conceptes que la física ha desenvolupat (el principi de conservació de l'energia) i unes fórmules molt més concretes per a cassos molt particulars (el canvi d'entalpia que cal fer perquè un volum determinat d'aire passi d'unes condicions a altres)
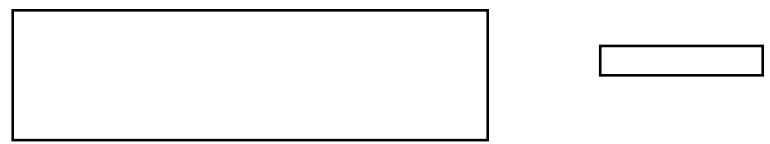

Figura 10. Els rectangles representaran els conceptes de física.

Es poden, aleshores, establir múltiple relacions entre una o vàries el-lipses i un o varis rectangles però cal partir d'un punt clau:

"Un rectangle MAI pot cobrir exactament una el-lipse"

$\mathrm{Hi}$ ha com diem, múltiples possibilitats d'operació que anem a classificar en "relacions externes" i "interseccions" (Roset, Serra; 2006). 
Podem utilitzar les "relacions externes" per a preparar un curs de física per arquitectura. Partint de la primera idea del responsable d'arquitectura, es produeix un seguit de respostes i noves demandes que porten a relacionar alguns grans conceptes entre ells i, també, alguns dels petits conceptes (figura 11).

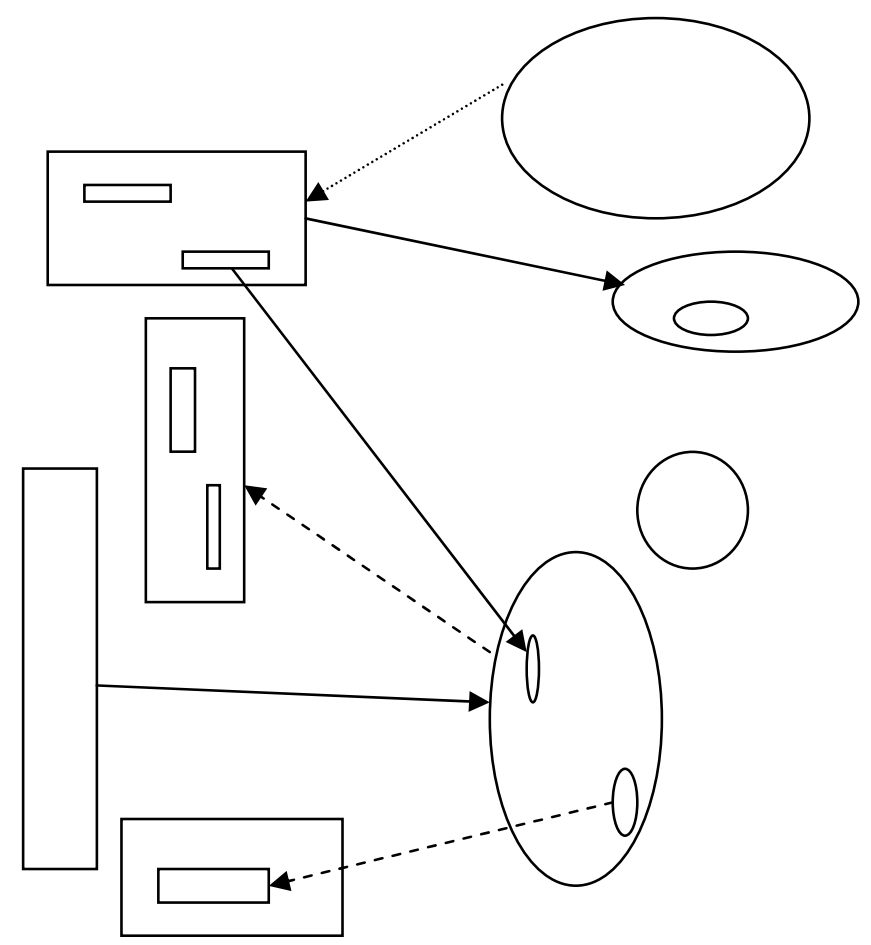

Figura 11. Procés d'interacció que porta cap a la definició d'un curs de física per arquitectura.

Després del procés en què ja hem decidit els principals conceptes a tractar, cal concretar-los més. Son les "interseccions" que ja ens indicaran com farem els capítols concrets de l'assignatura proposada.

De vegades, haurem de decidir entre dos enfocaments diferents. En la figura 12, podem veure que els mateixos tres conceptes arquitectònics poden ésser tractats mitjançant tres conceptes físics diferents o amb un gran concepte físic del que es deriven tres petits conceptes.

a)
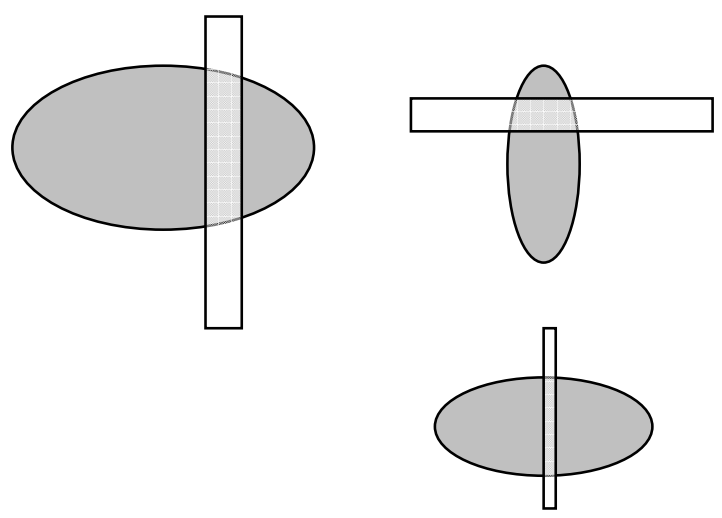


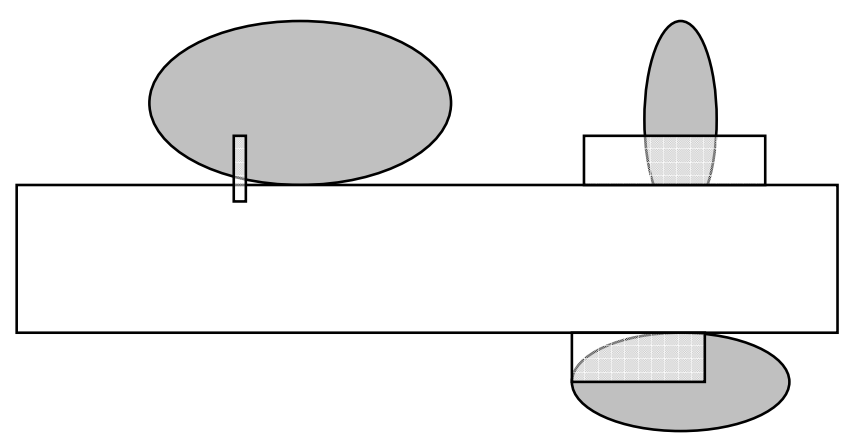

b)

Figura 12. Dues maneres d'enfocar els mateixos conceptes arquitectònics.

Nosaltres som, en general, partidaris del que es veu en la part b): una explicació dels conceptes més potents possibles.

El llenguatge el.lipse / rectangle ens permet una total flexibilitat a l'hora d'estudiar altres formes d'intersecció que representen idees que volem portar a la pràctica (els detalls estan en el capítol 4 de la tesi). Així, plantegem-nos el problema de fer evolucionar els conceptes per a ajustar-se millor a les necessitats de l'estudiant.

Si es tracta d'un únic concepte, pot ésser que el concepte arquitectònic s'acosti al concepte físic. Parlaríem aquí d'una arquitectura que intenta aprofitar nous desenvolupaments de la física, nous materials, ...

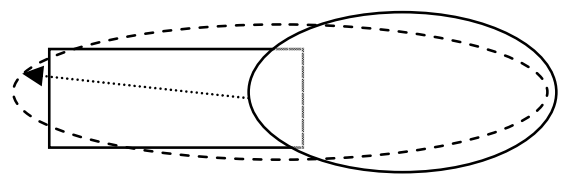

Figura 13. El concepte arquitectònic s'acosta al concepte físic

Pot, d'altra banda, passar que el concepte físic s'acosti al concepte arquitectònic. És a dir, que se cerquin unes formulacions més precises de conceptes arquitectònics que, encara, no les tenien (veure els programes CLA92 i Archisun a www.upc.es/aie)

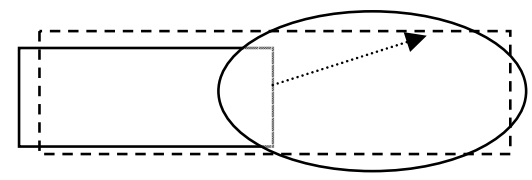

Figura 14. El concepte físic s'acosta al concepte aruitectònic 
.En el moment de passar als detalls, sempre caldrà que alguns conceptes físics 'petits' ajudin a un 'gran' per a aproximar-se a parts concretes del concepte (preferiblement "gran concepte") arquitectònic.

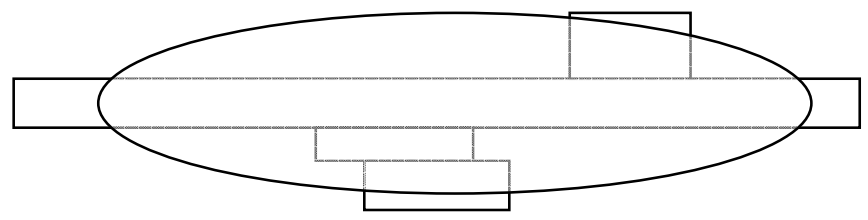

Figura 15. Tres conceptes físics petits ens permeten acostar-nos al concepte arquitectònic.

Com a conclusions d'aquesta part, direm que hem "creat" un llenguatge que ens permet relacionar els conceptes arquitectònics i físics de manera que ens permetran fer unes propostes que, començant de manera general, podrem arribar a detallar.

No voldríem acabar sense proposar el que seria el nostre ideal: Que cada concepte físic hagi d'estar pensat de manera que es pugui utilitzar per a ajudar a entendre diversos conceptes arquitectònics.

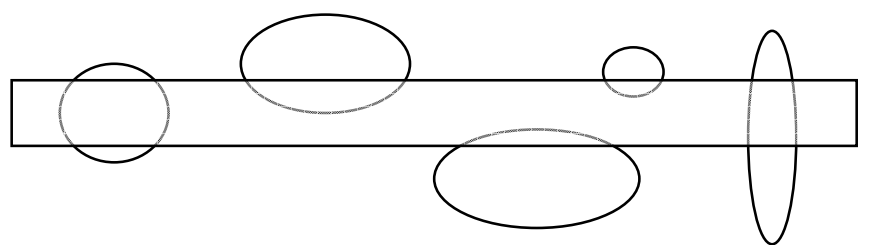

Figura 16. Cada concepte físic està pensat de manera que pot donar serveis a diversos conceptes arquitectònics.

Per acabar, cal haver pensat com combinar conceptes físics per a possibles necessitats de l'arquitectura.

\section{Proposta de sistema de transmissió.}

Anem a proposar un possible sistema genèric d'organització de la informació que segueix les condicions i el tipus de desenvolupament esmentats en el capítol 2.

En aquest cas particular, s'incideix en el control permanent dels Resultats. En efecte, seran tres les vegades en què els presentarem. Al començar les explicacions per a donar una "primera idea" del que pretenem, després de triar quins principis bàsics de la física pensem utilitzar ("esperats") i, en acabar, com una mena de resum final del que haurem "obtingut". 


\begin{tabular}{|l|l|}
\hline Resultats 1 (primera idea) & $\begin{array}{l}\text { Pensar en una base "comuna" els fenòmens que } \\
\text { puguin ésser utilitzats en les matèries de física } \\
\text { general o estàtica o condicionament ambiental a } \\
\text { l'arquitectura o serveis d'instal.lacions. }\end{array}$ \\
\hline Principis de la física & $\begin{array}{l}\text { Conservació energia, lleis de la mecànica o de la } \\
\text { calor i transmissió de calor, lleis de la radiació... }\end{array}$ \\
\hline Resultats 2 (esperats) & $\begin{array}{l}\text { Conèixer les variables habituals. } \\
\text { Saber avaluar els exercicis bàsics. } \\
\text { Significat dels valors recomanats i normatius. }\end{array}$ \\
\hline Processos (fórmules de càlcul) & $\begin{array}{l}\text { Construcció i ús d'eines (preferentment gràfiques) } \\
\text { que s'han d'aplicar en: } \\
\text { - Models senzills } \\
\text { - Relacions senzilles } \\
- \text { Models i relacions més elaborats... }\end{array}$ \\
\hline Conseqüències & $\begin{array}{l}\text { Càlculs de variables d'interès en diferents } \\
\text { situacions... }\end{array}$ \\
\cline { 2 - 3 } & \\
\cline { 2 - 3 } & $\begin{array}{l}\text { Valors obtinguts davant valors de referència (per } \\
\text { exemple, normatives). Utilitzar mesures sempre } \\
\text { que sigui possible. }\end{array}$ \\
\hline Comparacions & $\begin{array}{l}\text { Possibilitat que els estudiants puguin formalitzar } \\
\text { normatives (tipus NBE-CT-79, NBE-CA-88...). }\end{array}$ \\
\cline { 2 - 3 } & $\begin{array}{l}\text { Les comparacions amb valors mesurats mostren } \\
\text { que "manquen coses" (en llum, per exemple, cal } \\
\text { considerar més d'una reflexió!) }\end{array}$ \\
\hline Resultats 3 (obtinguts) & \\
\hline
\end{tabular}

Taula 4. Una proposta de forma general de preparar els temes

Aquesta representació, en forma de taula, es va omplint successivament per a les assignatures (gràficament, amb les relacions externes rectangles - el-lipses) i pels capítols de les assignatures (gràficament, amb les interseccions rectangles - el-lipses). 


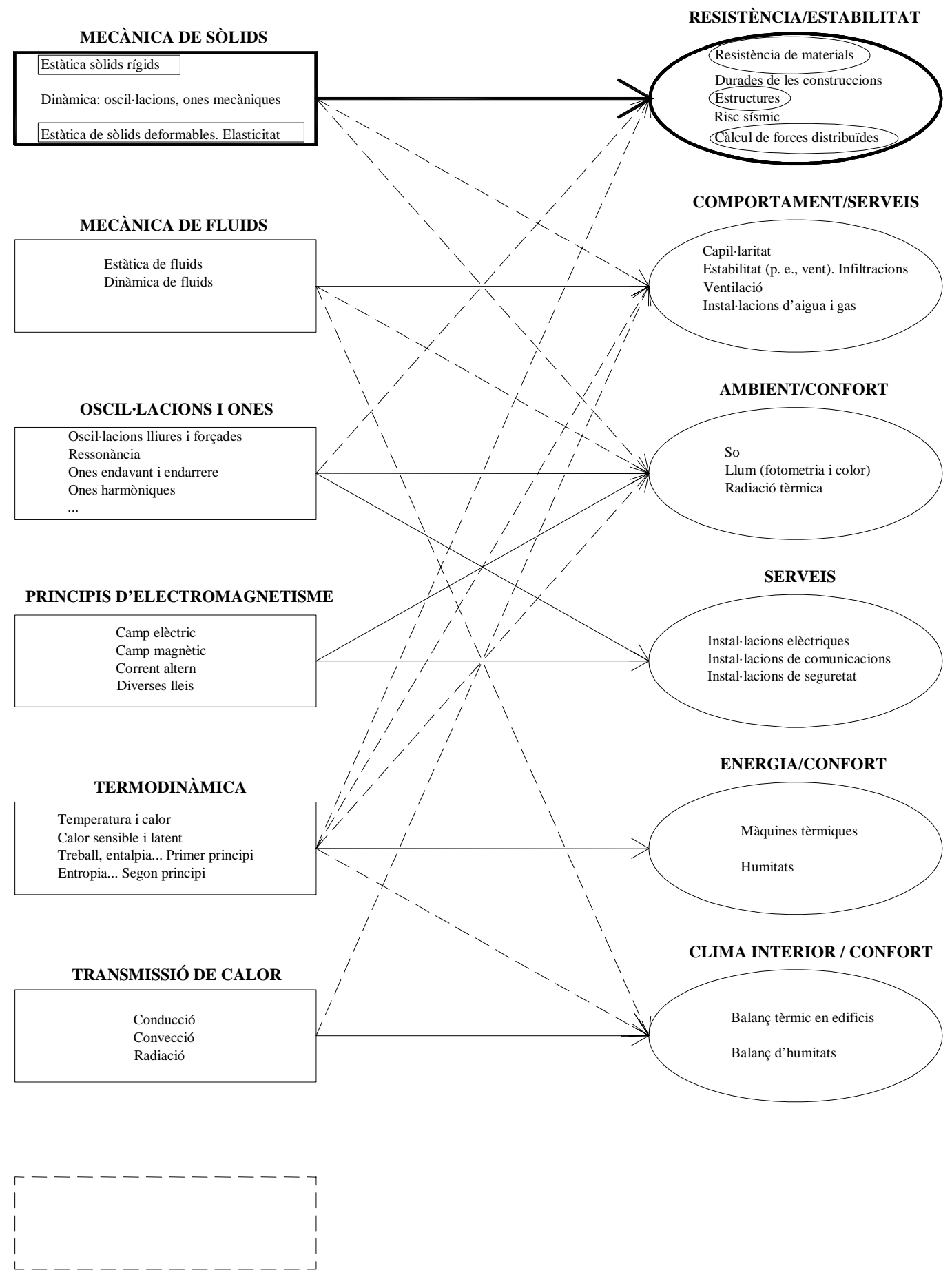

Figura 17. Representació de relacions externes d'una assignatura concentrada 
La mateixa assignatura, vista mitjançant les interseccions podria tenir la forma següent:

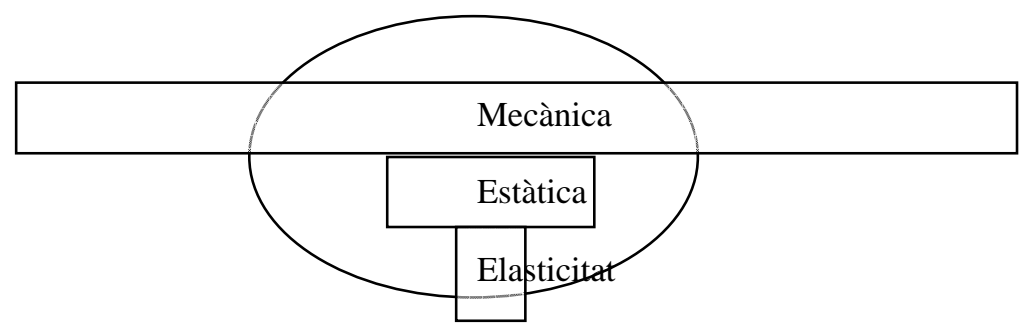

Figura 18. Representació amb interseccions d'una assignatura concentrada.

Es tractaria, doncs, d'una matèria que podem explicar d'una forma deductiva a partir d'uns pocs principis (lleis de Newton, en aquest cas) complementats amb algunes relacions constitutives (rigidesa, llei de Hooke).

Per contra, una assignatura amb coneixements més dispersos agafaria la forma:

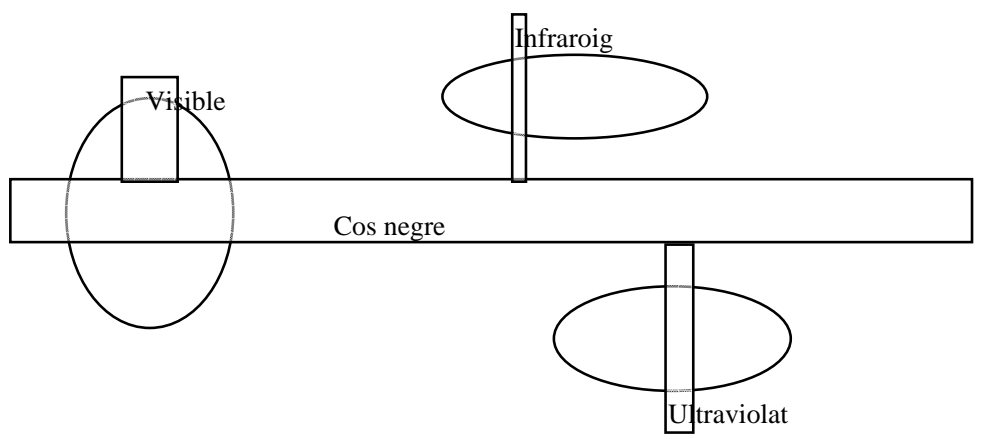

Figura 19. Representació amb interseccions d'una assignatura ramificada.

Necessitaríem en aquestes matèries, una descripció verbal molt més àmplia (en aquest cas dels efectes de les diferents longituds d'ona de l'espectre electromagnètic). Els professors menys experimentats en la impartició de classes en arquitectura solen trobar aquest tipus d'assignatures "incòmodes" des d'un punt de vista intel.lectual.

\section{Exemplificació}

Ens arriba ja el moment d'exemplificar tot el que hem estat comentant amb un cas concret totalment desenvolupat. Anem a utilitzar l'assignatura Física de Medi Ambient a l'Arquitectura i el capítol Física pel confort tèrmic a l'arquitectura. Omplim la taula pel cas concret de l'assignatura: 


\begin{tabular}{|c|c|}
\hline Resultats 1 (primera idea) & $\begin{array}{l}\text { Pensar en una base "comuna" els fenòmens que } \\
\text { puguin ésser utilitzats en les matèries de } \\
\text { Condicionament Ambiental a l'Arquitectura. } \\
\text { (vegeu AIE) }\end{array}$ \\
\hline Principis de la física: & $\begin{array}{l}\text { Tèrmica, Llum i So (vegeu EVE, capítol } 2 \text { i FLS, } \\
\text { capítols } 2 \text { a 5) }\end{array}$ \\
\hline Resultats 2 (esperats) & $\begin{array}{l}\text { En temes de Tèrmica, Llum i So, conèixer les } \\
\text { variables habituals. Saber avaluar els exercicis } \\
\text { bàsics de psicrometria, transmissió de calor, } \\
\text { il-luminació i nivells de so. "Percepció" dels valors } \\
\text { recomanats i normatius. }\end{array}$ \\
\hline \multirow[t]{4}{*}{ Processos (fórmules de càlcul) } & Construcció i ús de l'àbac psicromètric. \\
\hline & $\begin{array}{l}\text { Model estacionari 1D de tipus conductiu (amb } \\
\text { idea d'infiltracions) de transferència de calor. } \\
\text { Càlcul de diagrames de prevenció de } \\
\text { condensacions. }\end{array}$ \\
\hline & $\begin{array}{l}\text { Magnituds i relacions fotomètriques. } \\
\text { Teoria del color. }\end{array}$ \\
\hline & $\begin{array}{l}\text { Nivell d'intensitat sonora. Reverberació i } \\
\text { transmissió del so. }\end{array}$ \\
\hline \multirow[t]{5}{*}{ Conseqüències } & $\begin{array}{l}\text { Quantitat de calor que cal intercanviar per passar } \\
\text { d'un estat de temperatura/ humitat } a \text { un altre. }\end{array}$ \\
\hline & $\begin{array}{l}\text { Flux de calor que travessa una paret de diverses } \\
\text { capes, una paret amb parts opaca i vidrada, un } \\
\text { recinte tancat.Idea de si hi haurà condensació o } \\
\text { no en un tancament. }\end{array}$ \\
\hline & $\begin{array}{l}\text { II.luminàncies conegudes les fonts primàries i } \\
\text { secundàries presents. }\end{array}$ \\
\hline & Exercicis de barreges de colors. \\
\hline & Nivells sonors en interiors \\
\hline Comparacions & $\begin{array}{l}\text { Valors obtinguts respecte a valors en normatives. } \\
\text { Algunes mesures amb termòmetres, higròmetres, } \\
\text { luxòmetres i sonòmetres. }\end{array}$ \\
\hline \multirow[t]{2}{*}{ Resultats 3 (obtinguts) } & $\begin{array}{l}\text { Els estudiants poden complimentar normatives } \\
\text { tipus NBE-CT-79, NBE-CA-88 }\end{array}$ \\
\hline & $\begin{array}{l}\text { Les comparacions amb valors mesurats mostren } \\
\text { que "manquen coses" (en llum, per exemple, } \\
\text { considerar més d'una reflexió!) }\end{array}$ \\
\hline
\end{tabular}

Taula 5. Assignatura Física del Medi Ambient a l'Arquitectura. 
A continuació, d'acord amb els responsables de la part d'Arquitectura, seleccionem els conceptes de Física a impartir en relació als conceptes arquitectònics esperats.

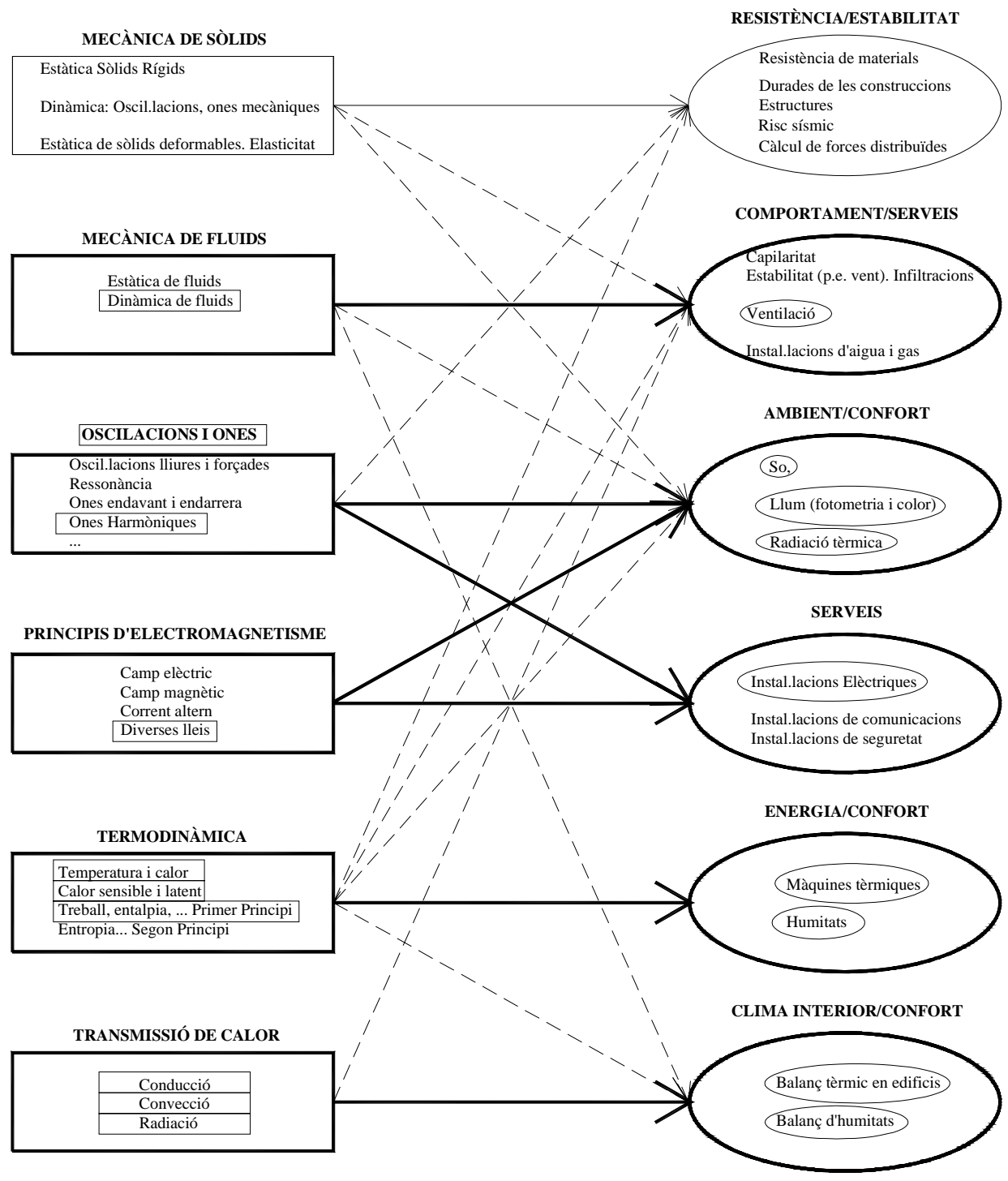

Figura 20. Selecció dels grans i petits conceptes de Física i Arquitectura implicats en l'assignatura. 
Arriba ja el moment de posar-ho per capítols. En aquest cas, l'assignatura tenia 45 hores de classe i es va dividir en dues parts:

Capítol 1. Física per al confort tèrmic a l'Arquitectura

Capítol 2. Física de la llum i el so.

L'experimentació es va decidir fer amb el capítol 1. Apliquem la transmissió de la calor a la roba, la pell i a través de l'aire en la respiració. Aquests coneixements ja els havíem treballat prèviament en explicar transmissió de la calor en general i havien servit per a poder-la avaluar en el cas d'un edifici en règim estacionari.

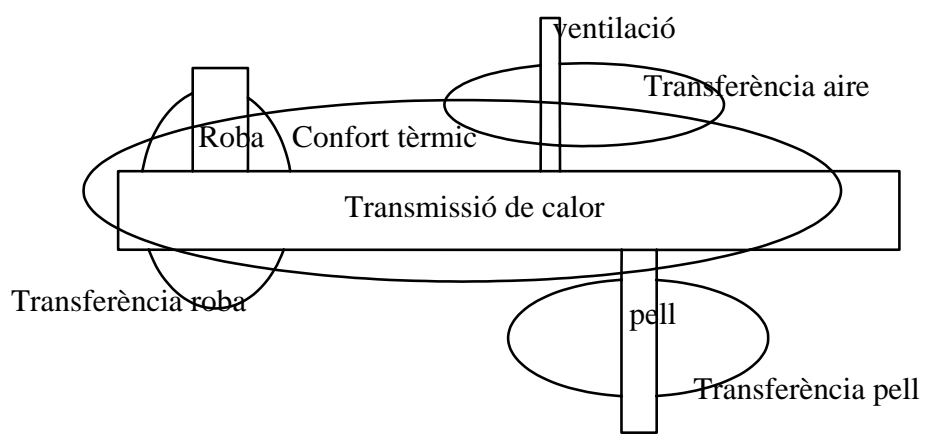

Figura 21. Explicació de la transmissió de la calor. A efectes d'estudiar el confort, s'aplica a la roba, a la pell i a l'aire que respirem.

És clar, tot això s'havia de provar i es va fer una experimentació amb estudiants en el decurs del quadrimestre de primavera de l'any 2004. L'experimentació va consistir en explicar el mateix tema a dos subgrups d'estudiants fent una classe diferenciada per exercicis elaborats explicats de manera gràfica o numèrica. Després, examinàvem en conseqüència. Això es va repetir en quatre ocasions, de manera que cada estudiant fos examinar dues vegades de manera gràfica i altres dues de manera matemàtica.

Els temes triats per als exàmens van ésser:

a) Relacions entre calor, temperatura i humitat: psicrometria.

b) Previsió de condensacions en estat estacionari.

c) Avaluació de confort tèrmic en estat estacionari.

(el següent, s'ha afegit per completar un nombre parell d'exercicis)

d) Suma de decibels en exercicis d'acústica. 
12 Architecture, City, and Environment

Arquitectura, Ciudad y Entorno

Es presenta, a continuació, un resum del material utilitzat:

\begin{tabular}{|c|c|c|c|c|}
\hline Tema & $\begin{array}{l}\text { Material } \\
\text { comú }\end{array}$ & Fórmules & Gràfic & Examen \\
\hline Psicrometria & $\begin{array}{l}\text { Calor } \\
\text { sensible i } \\
\text { calor latent }\end{array}$ & $p_{\text {sat }}=611 * e^{17,15 \frac{t}{t+2}}$ & 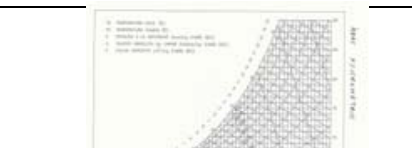 & $\begin{array}{l}\text { Aire en } \\
\text { condicions } \\
\text { de confort }\end{array}$ \\
\hline Condensacions & No n'hi ha & $T_{m, B A I X A}=T_{B A I X A}+c$ & & $\begin{array}{l}\text { Preveure } \\
\text { condensació } \\
\text { en paret de } \\
2 \text { capes }\end{array}$ \\
\hline Confort tèrmic & $\begin{array}{l}\text { Balanç } \\
\text { sobre cos } \\
\text { humà }\end{array}$ & $P P D=100-95 . e^{-\gamma}$ & \begin{tabular}{|c|c|c|c|} 
\\
\end{tabular} & $\begin{array}{l}\text { Probable } \\
\text { situació de } \\
\text { confort } \\
\text { tèrmic }\end{array}$ \\
\hline Acústica & $\begin{array}{l}\text { Definició } \\
d B\end{array}$ & $N_{1+2}=10 \cdot \log \left(\frac{I_{1}+I_{2}}{I_{0}}\right)$ & | & $\begin{array}{l}\text { Nivells } \\
\text { intensitat } \\
\text { sonora }\end{array}$ \\
\hline
\end{tabular}

Taula 6. Resum del material dels tests realitzats amb el grup d'estudiants de Física de Medi Ambient a l'Arquitectura a la primavera del 2004 
Els resultats dels exàmens amb estudiants han mostrat, pràcticament, les mateixes notes. On s'ha vist una separació important ha estat en el temps de realització de l'examen quan s'ha utilitzat un gràfic ben desenvolupat (com és el cas de l'àbac psicromètric). En aquest cas,els alumnes necessiten menys temps per a realitzar correctament el mateix examen. Quan el gràfic no està suficientment desenvolupat, no s'observa diferència.
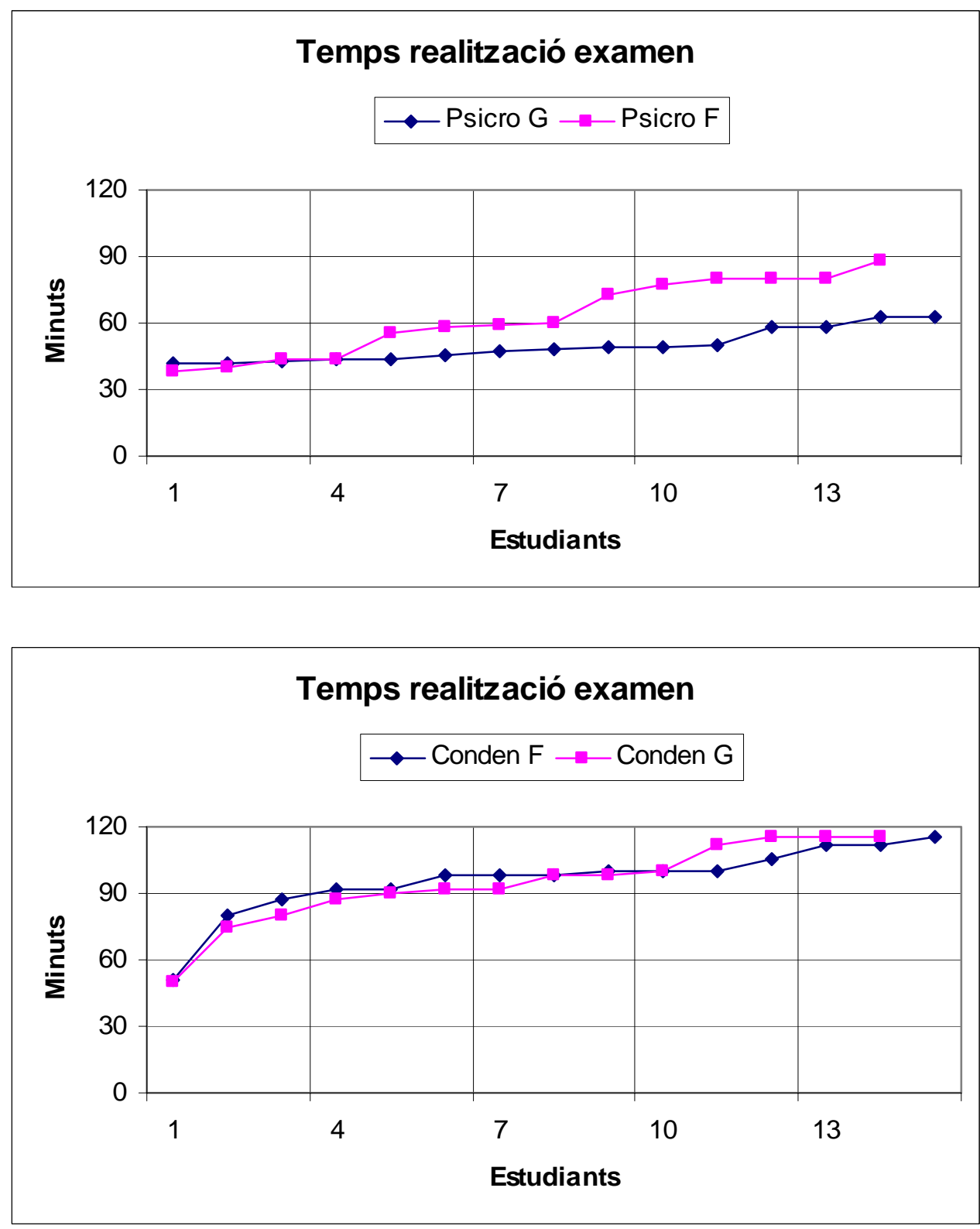

Figura 22. En el cas d'un gràfic ben desenvolupat, els alumnes resolen l'examen en un temps significativament menor. No és així quan l'elaboració del gràfic no està tan clara. 
Amb un llenguatge clàssic, valoraríem d'aquest treball que hem aconseguit transmetre als nostres estudiants:

- Coneixements sobre termodinàmica, sobre com fer balanços d'energia, les lleis de Fourier $i$ de Fick i la seva aplicació per a parets planes en régim estacionari. A més, hem justificat algunes aproximacions lineals usuals i els hi hem mostrat l'ús d'aparells de mesura i programes d'ordinador.

- Habilitats per a utilitzar l'àbac psicromètric, construir diagrames de condensacions i fer càlculs de confort.

- Els nostres estudiants han aprés a tenir una actitud activa en front a les qüestions de confort tèrmic.

En el llenguatge d'aquest treball:

\begin{tabular}{|c|c|}
\hline $\begin{array}{l}\text { Resultats } 1 \\
\text { (primera idea) }\end{array}$ & $\begin{array}{l}\text { Conèixer el confort tèrmic. } \\
\text { Pensar com part del confort integrat. }\end{array}$ \\
\hline Principis & Balanços d' energia. \\
\hline $\begin{array}{l}\text { Resultats } \\
\text { (esperats) }\end{array}$ & $\begin{array}{l}\text { Afinar la seva percepció del confort tèrmic. } \\
\text { Conèixer els valors de referència. }\end{array}$ \\
\hline Processos & Balanços estacionaris prop de la situació de confort. \\
\hline Conseqüències & Càlcul del desequilibri del flux tèrmic. \\
\hline Comparació & Contrast amb els valors de Fanger. \\
\hline $\begin{array}{l}\text { Resultats } \\
\text { (obtinguts) }\end{array}$ & $\begin{array}{l}\text { Alumnes capaços de realitzar balanços tèrmics } \\
\text { estacionaris. } \\
\text { També, de calcular diagrames de condensacions. }\end{array}$ \\
\hline
\end{tabular}

Taula 7. Valoracions dels exàmens i de l'observació dels estudiants seguint el llenguatge d'aquest treball.

El conjunt de les valoracions ens porta a concloure que els coneixements, les habilitats i les actituds dels estudiants d'Arquitectura augmenten si s'incorpora un contingut gràfic DE QUALITAT a la presentació que se'ls fa dels principis, processos/conseqüències i resultats del tema de confort tèrmic. Pensem que aquesta conclusió es pot extrapolar a qualsevol altre tema en particular, a tota l'assignatura i al conjunt dels estudis d'un o més cursos d'Arquitectura. 


\section{Conclusions de la tesi i noves propostes}

La conclusió general d'aquesta tesi és que:

"Una explicació de física per a arquitectes ha de tenir un important contingut gràfic en tots els seus estadis"

Creiem que aquesta idea és podria generalitzar a qualsevol bona comprensió entre els llenguatges de dues disciplines.

Una altra conclusió, també de caire general, seria que tota la tesi segueix l'esquema proposat en el capítol 5. En la següent taula mostrem com:

\begin{tabular}{|l|l|}
\hline $\begin{array}{l}\text { Resultats 1 } \\
\text { (primera idea) }\end{array}$ & Física a estudiants d'arquitectura \\
\hline Principis & Establiment del sistema de transmissió \\
\hline $\begin{array}{l}\text { Resultats } \mathbf{2} \\
\text { (esperats) }\end{array}$ & Transmetre els continguts seleccionats \\
\hline Processos & Llenguatge rectangles - el·lipses \\
\hline Conseqüències & Proposta de sistema per a l'ensenyament \\
\hline Comparació & Comparació amb el que esperàvem \\
\hline $\begin{array}{l}\text { Resultats 3 } \\
\text { (obtinguts) }\end{array}$ & Conclusions, aquesta tesi \\
\hline
\end{tabular}

Taula 8 . El conjunt de la tesi es pot pensar com una aplicació de la proposta del capítol 5.

També, podem assenyalar unes conclusions per capítols. En forma de taula:

\begin{tabular}{|l|l|}
\hline Capítol & Aportació realitzada \\
\hline $\mathbf{1}$ & Classificar els gràfics per tipus \\
\hline $\mathbf{2}$ & Transmetre la física tal com es fa \\
\hline $\mathbf{3}$ & Explicar física habitual adaptada \\
\hline $\mathbf{4}$ & Esquema gràfic per a conceptes físico-arquitectònics \\
\hline $\mathbf{5}$ & $\begin{array}{l}\text { Taula per a preparar qualsevol tema disciplinari per a ésser impartit a públic no } \\
\text { especialitzat }\end{array}$ \\
\hline $\mathbf{6}$ & Desenvolupament complet per explicar física pel confort tèrmic a l'arquitectura. \\
\hline
\end{tabular}

Taula 9 . Conclusions obtingudes per capítols 
És, també, una idea d'una tesi, el servir per a generar "noves propostes" que puguin ésser seguides per altres persones interessades en el camp en què hem treballat. A continuació descrivim algunes d'elles:

Com a continuació directa de la tesi:

- Construir gràfics operatius útils

- Preparar física per arquitectes de postgrau

- Estendre el llenguatge el.lipse- rectangle

- Estudiar altres propostes de sistema d'organització: processos

- Preparar altres assignatures i capítols

Com a continuació indirecta:

- Preparar un treball per a poder explicar "Física aplicada al medi ambient en general"

\section{Una reflexió més personal}

Aquest treball de tesi l'he realitzat al llarg de molt, segurament massa, temps. En aquest emps, hi ha algunes qüestions que no son tècniques però que han influït en la meva manera d'enfocar el tema. Hi ha una que voldria citar aquí: va ésser reconèixer que totes les persones som úniques i irrepetibles i decidir preparar una manera d'ensenyar bassada en el RESPECTE a aquesta característica.

Tractar a cada estudiant d'una forma personalitzada, intentant localitzar les barreres que tenia per a la comprensió dels temes (molts cops la presentació amb massa fórmules dels exercicis) ha estat una de les claus per a aconseguir passar-ho bé en la tasca de transmetre coneixements de física als futurs arquitectes.

Finalment, dir que en el treball de preparar la presentació de la tesi ha estat molt important l'aportació d'algunes persones que no apareixen explícitament en els agraïments de la tesi (Cristina Pardal, Maria Lourdes Roset, Mauricio Ortigosa)

Un desig: m'agradaria que físics i arquitectes seguíssin treballant conjuntament

\section{Bibliografia}

MONEDERO, J. (2003) Enseñanza y práctica profesional de la arquitectura en Europa y USA. Publicaciones ETSAB, Barcelona.

ROSET, J. (2006) Física aplicada a l'ensenyament de l'arquitectura. UPC, Barcelona ROSET, J., SERRA, R. (2006) A language for representation of physic-architectural concepts. World Renewable Energy Congress IX. p. LEA66 (6 pàgines). Florencia 